\title{
59. DOWN-HOLE TEMPERATURE MEASUREMENTS AND HEAT FLOW AT HESS RISE, DEEP SEA DRILLING PROJECT LEG $62^{1}$
}

\author{
Naoyuki Fujii, Department of Earth Sciences, Kobe University, Nada, Kobe 657, Japan
}

\begin{abstract}
Heat-flow measurements have been made in two holes at Deep Sea Drilling Project Site 465, southern Hess Rise, using a recently developed down-hole temperature probe. From the temperature difference between sub-bottom depths of 86.5 and 172 meters, a heat-flow value of $1.36 \mathrm{HFU}\left(56.7 \mathrm{~mW} / \mathrm{m}^{2}\right)$ is obtained. This value is nearly the same as the mean value for crustal rocks of the North Pacific basin about 100 m.y. old (the age of the oldest sediments at Site 465).
\end{abstract}

\section{INTRODUCTION}

The extent of Hess Rise is comparable to that of Schatsky Rise, the Ontong-Java Plateau, and the MidPacific Mountains in the central and northwestern Pacific Ocean. The volcanism which produced these topographic highs occurred during the Early Cretaceous to the Late Jurassic (Moberly and Larson, 1975; Tokuyama, in press). To clarify the origin and extent of the volcanic activity related to formation of rises and plateaus, heat-flow measurements at these topographic highs, compared with those of the surrounding ocean floor basin, would provide some clues.

Taken at depths of only 2 to 5 meters penetration of the temperature probe, the normal heat flow measurements might be subject to the effects of temperature variations of bottom sea water, especially at the relatively shallow water depths of rises and plateaus. Thus, temperature measurements in a deep hole (hundreds of meters) drilled by DSDP are expected to provide morereliable heat-flow values for these regions.

Down-hole temperature measurements were attempted on southern Hess Rise at DSDP Site 465 (water depth $2161 \mathrm{~m}$ ), using the Tokyo-T probe, which recently has been developed and successfully operated during Leg 60 (Uyeda and Horai, in press). The probe consists of a thermister housed in the head of the nose piece of the in situ water sampler of R. Barnes; it measures and stores temperatures at 1-min (or 2-min) intervals, recording as many as 128 measurements in a solid-state memory while being lowered and inserted into undrilled sediments at the bottom of the hole through the bit. More-detailed descriptions of the Tokyo-T probe are given by Yokota et al. (in press).

Down-hole temperature measurements using the Tokyo-T probe and also the Erickson-type probe (Erickson, 1974) are normally limited to regions where sediments are sufficiently thick and soft (Hyndman et al., 1977; Uyeda and Horai, in press).

This report presents measurements of down-hole temperature, thermal-conductivity, and heat flow at

\footnotetext{
${ }^{1}$ Initial Reports of the Deep Sea Drilling Project, Volume 62.
}

DSDP Site $465\left(33^{\circ} 49.23^{\prime} \mathrm{N}, 178^{\circ} 55.14^{\prime} \mathrm{E}\right)$, conducted during Leg 62.

\section{TEMPERATURE MEASUREMENTS}

Four down-hole temperature measurements were tried in Holes 465 and $465 \mathrm{~A}$ between sub-bottom depths of 80 and 200 meters. As the thermal time constant of the whole assembly of the Tokyo-T probe was a few minutes, the probe was stopped at the mudline (sea floor) and at the undrilled sediments for at least $20 \mathrm{~min}$, to obtain temperatures within an accuracy of $\leqslant 0.1^{\circ} \mathrm{C}$ at each depth (see section on accuracy of methods). The absolute accuracy of the temperature measurement by the probe was within $0.05^{\circ} \mathrm{C}$ by using a calibrated standard mercury thermometer as described in the section on accuracy of methods. The general operation and procedure of down-hole temperature measurements were similar to those used during Leg 60 (Uyeda and Horai, in press).

Figures $1 \mathrm{~A}$ and $1 \mathrm{~B}$ show the temperatures recorded at 1-min intervals, with elapsed time, for sub-bottom depths of 86.5 meters (Hole 465) and 172 meters (Hole $465 \mathrm{~A}$ ), respectively. In the first measurement in Hole 465 , the probe was stopped at the mudline for $20 \mathrm{~min}$ both before and after insertion into the undrilled bottom-hole sediments, and it showed a fairly constant temperature of $2.2 \pm 0.05^{\circ} \mathrm{C}$ (Fig. 1A). However, the temperatures during the insertion of the probe into bottom sediments fluctuate with time, ranging from 6.1 to $6.9^{\circ} \mathrm{C}$, as indicated in the insert in Figure 1A. There is a possibility that this fluctuation is due to the effects of the up-and-down motion of the bit and drill string during the measurements. This motion could cause heating of the probe by the friction between instruments and sediments, and cooling by the penetration of bottomhole water along the nose piece of the probe. We took an average value of $6.5( \pm 0.3)^{\circ} \mathrm{C}$ as a representative of the temperature at the sub-bottom depth of 86.5 meters.

The three other down-hole temperature measurements were tried in Hole 465A. The data were lost owing to disconnection of the battery power line in the second trial. The third measurement, at a sub-bottom depth of 115 meters, gave disturbed and very low temperature data just after the probe was latched into the 


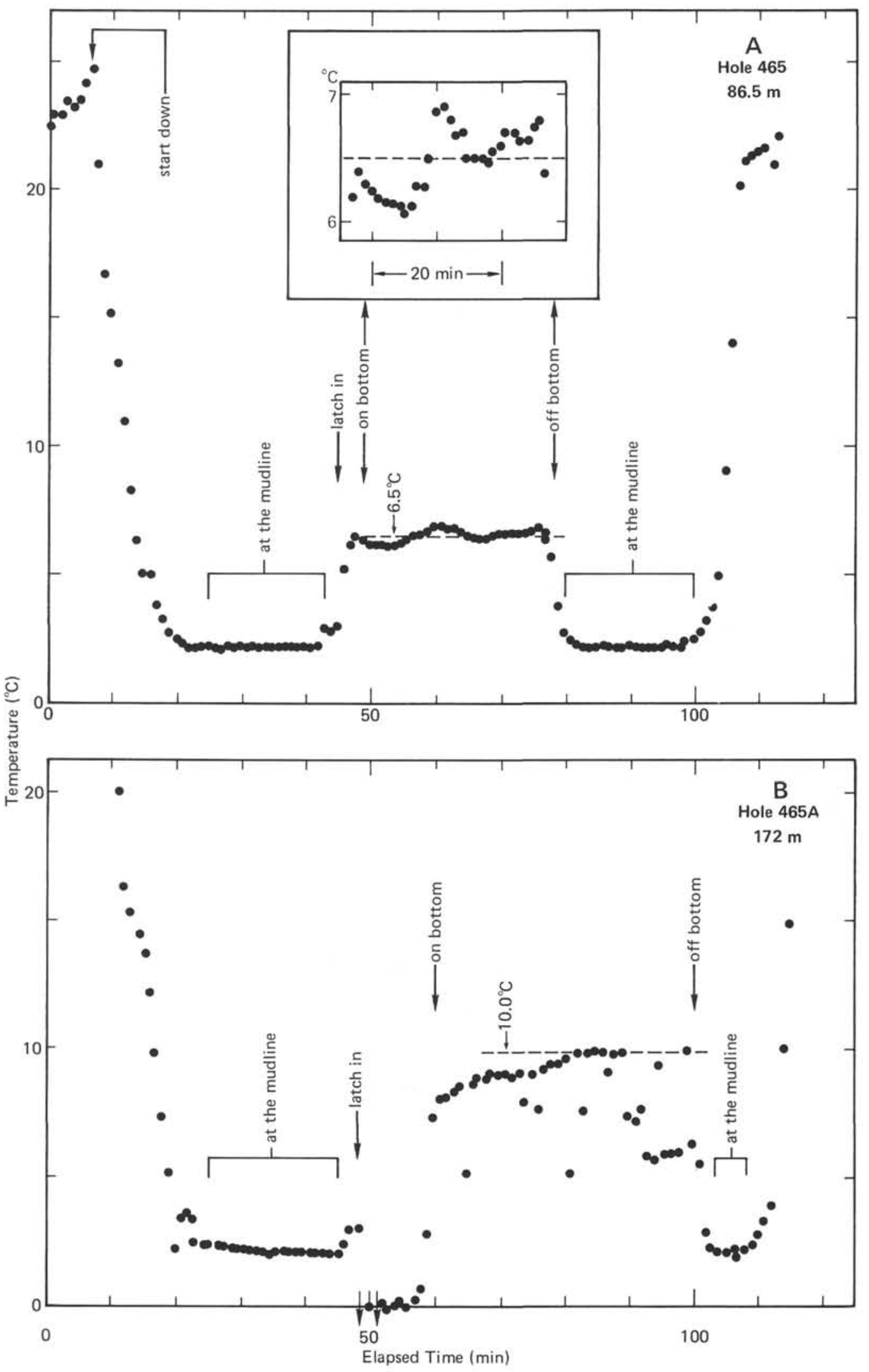

Figure 1. A. Down-hole temperature data at a sub-bottom depth of 86.5 meters in Hole 465 . Temperature variations of undrilled sediments with time are indicated in the insert, with expanded temperature scale. B. Downhole temperature data at a sub-bottom depth of 172 meters in Hole 465A. 
bit, whereas the mudline temperature was correctly recorded as $2.3( \pm 0.1)^{\circ} \mathrm{C}$ (Site 465 report, this volume). Although the causes of this disturbance remain unknown, heavy shocks at latch-in time or hitting hard sediment blocks, such as the chert chips in recovered cores, may cause damage to the temperature probe and memory devices. The temperature of the bottom-hole sediment shows a gradual increase in the fourth measurement, at a sub-bottom depth of 172 meters, and it tends to level off around $10.0^{\circ} \mathrm{C}$, although lower temperatures (a few degrees to $5^{\circ} \mathrm{C}$ ) were obtained intermittently (Fig. 1B). The mudline temperatures in the fourth measurement, both before and after insertion of the probe into undrilled sediments, show almost the same value of $2.3 \pm 0.1^{\circ} \mathrm{C}$ (Fig. 1B). It was confirmed by testing the probe system on board just after the measurement that the disturbed temperature records shown in Figure 1B were not due to damage to the thermister sensor.

Because the ship drifted off the beacon at Hole 465, Hole $465 \mathrm{~A}$ was drilled at the same latitude and longitude within the precision of ship location; the distance between the two holes should be so small that the temperature gradient would be the same. As discussed in detail in a later section, the following values will be used as formation temperatures: $6.5 \pm 0.3^{\circ} \mathrm{C}$ at 86.5 meters sub-bottom in Hole 465 , and $10.0^{\circ} \mathrm{C}$ at 172 meters in Hole $465 \mathrm{~A}$. The corresponding temperature gradient in this depth range is $40.9^{\circ} \mathrm{C} / \mathrm{km}$.

\section{THERMAL CONDUCTIVITY AND HEAT FLOW}

Thermal conductivity was measured by using a QTM (Quick Thermal Conductivity Meter, Showa Denko Co., Ltd.; Sumikawa and Arakawa, 1974). This method, which is in principle the same as the needle-probe method (Von Herzen and Maxwell, 1959), is particularly useful, both for unconsolidated sediments and for hard rocks, and gives no disturbance.

Because the water-content variation and disturbance of the recovered sediments could cause a considerable uncertainty in the measurement, the relative accuracy was within $10 \%$, whereas the theoretical accuracy was better than a few percent. A more-detailed description of this method and a comparison with the needle-probe method were given by Horai (in press).

Thermal conductivity of the recovered sediments was measured on the split portions of cores that had been covered by Saran Wrap and left at least 3 hours after the arrival of the sample on deck. The measurements then were performed at room temperature $\left(\sim 32^{\circ} \mathrm{C}\right)$ on wet samples. The results are shown in Figure 2A. No depth dependence of thermal conductivity of sediments (nannofossil ooze) is apparent. The average value is $3.52 \pm$ $0.33 \mathrm{cal} \times 10^{-3} / \mathrm{cm}-\mathrm{s}^{-}{ }^{\circ} \mathrm{C}$. After correcting for the pressure and temperature dependences (Ratcliffe, 1960; Erickson, 1974), the in situ thermal conductivity is calculated to be $3.32 \mathrm{cal} \times 10^{-3} / \mathrm{cm}-\mathrm{s}-{ }^{\circ} \mathrm{C}$. The temperature gradient of $40.9^{\circ} \mathrm{C} / \mathrm{km}$ (Fig. 2B) and the corrected value of thermal conductivity give a heat flow value of $1.36 \pm 0.2 \mathrm{HFU}$ for Site 465, southern Hess Rise.

\section{DISCUSSION}

As pointed out by Uyeda and Horai (in press), the operation of the Tokyo-T probe is limited to depth ranges corresponding to sediments which are soft enough after the bulk of the bottom-hole assembly ( $\sim 60 \mathrm{~m}$ long) is buried to some depth and the drill string system is stable; otherwise, the nose piece of the probe would be damaged. Down-hole temperature measure-

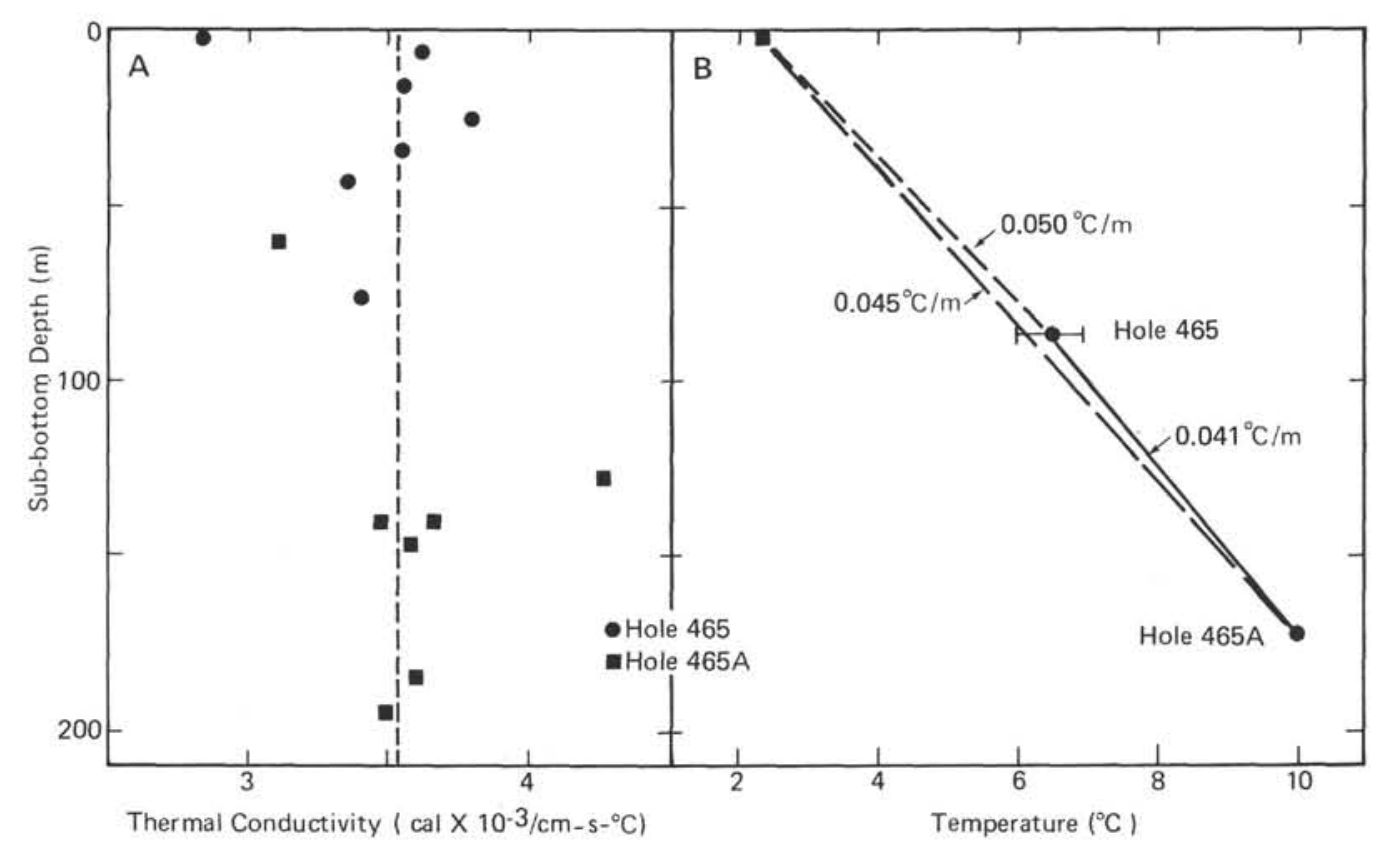

Figure 2. Thermal conductivity of sediments (A) and temperatures of undrilled sediments and of the mudline (B), plotted as a function of sub-bottom depth. 
ments by the Tokyo-T probe were normally made below sub-bottom depths of about 60 meters. When the recovered cores contain pieces of chert, and drilling slows because of the cherty sediments (normally experienced before reaching the hard rocks in the Pacific Ocean basin), operation of this probe becomes risky.

Many scratches on the surface of the nose piece of the probe were found after the third trial, to sub-bottom depths of 115 meters. These resulted from the probe hitting many pieces of chert in the sediments (Vallier, Thiede, et al., this volume). Penetration of the probe into the undrilled sediments could cause penetration of bottom-hole water between the nose piece and surrounding sediments, which would disturb the temperature recording. Especially when the sediments contain many chert chips, the up-and-down motion of the entire drill string during the temperature measurement of the undrilled sediments, could cause continuous or intermittent penetration of relatively cold bottom-hole water.

If the penetration of bottom-hole water is continuous, the disturbed and very low temperature observed in the third measurement is understandable. There are many other disturbing effects on temperature measurements of undrilled sediments, such as the variation of non-uniform stresses and frictions around the probe, and the up-and-down motion of the bit to which the probe is latched. However, if these disturbances are intermittent and relatively slight, the recorded temperature of the undrilled sediments could not be so affected, considering the thermal time constant (see section on accuracy of methods). Although the effects of these disturbances could not be estimated, the observed temperature variation in Figure 1B suggests that slight penetration of cold bottom-hole water would occur intermittently for $30 \mathrm{~min}$ after the probe was on bottom. The gradual increase and stabilization of temperature during this period seem to indicate that the true temperature of the undrilled sediments at a sub-bottom depth of 172 meters is about $10.0^{\circ} \mathrm{C}$.

\section{Mudline Temperature}

The mudline temperatures for Holes 465 and $465 \mathrm{~A}$ are 2.2 and $2.3^{\circ} \mathrm{C}$, respectively, as shown in Figures $1 \mathrm{~A}$ and $1 \mathrm{~B}$. If the recorded temperature during a $20-\mathrm{min}$ stop at the mudline represents the actual ocean-bottom temperature (Erickson, 1974; Hyndman et al., 1977), the temperature gradient can be estimated for each measurement. Temperature gradients thus calculated are $49.7^{\circ} \mathrm{C} / \mathrm{km}$ (Hole 465 ) and $44.8^{\circ} \mathrm{C} / \mathrm{km}$ (Hole $465 \mathrm{~A}$ ), and corresponding heat-flow values are 1.65 and $1.49 \mathrm{HFU}$, respectively. The assumption made in this calculation is that the temperature of the waters inside the drill pipe and the bottom-hole assembly is equilibrated to that of undisturbed ocean bottom a few hours after the cessation of drilling-water circulation. However, there remain some ambiguities. We cannot evaluate the disturbing effects of the bottom-hole assembly on temperature distribution near the ocean bottom, nor those of water circulation during drilling, even if the measurements were made more than 1 hour after the cessation of circulation and the 20-min stop of the temperature probe at the mudline. Also, the actual level of the mudline estimated by the wire line would be variable due to the variable surface conditions of the ocean bottom and bottom-hole assembly. We accept a heat flow value of $1.36 \mathrm{HFU}$ for this site, although the differences among the estimated values cannot be attributed confidently either to the differences of hole location or mudline temperature assumed in the estimation.

\section{Age of Hess Rise and Heat Flow}

The sediment just above the trachyte in Hole $465 \mathrm{~A}$ is late Albian. In Figure 3, heat-flow values are plotted against age of the oceanic crust; a "selected average" of North Pacific data (Sclater and Francheteau, 1970) and a theoretical curve are plotted together with the present value for Hess Rise. As seen in Figure 3, heat flow at Hess Rise almost coincides with North Pacific averaged data for sea-floor between 50 and 100 m.y. old. However, this is slightly higher than that expected from theory, based on the evolution of ocean basin at a midocean ridge. Hess Rise should not be younger than 50 m.y., judging from the heat-flow value. However, it is unknown whether Hess Rise was produced by mid-plate volcanism or generated at a mid-ocean ridge. Obviously, more-extensive investigations, both at the topographic highs and surrounding ocean basin, are needed to obtain conclusive results.

\section{ACCURACY OF METHODS}

To estimate the response and accuracy of the Tokyo-T probe, the entire assembly was put into the core-sample storage room, and the nose piece in which the thermister was housed was immersed in water at $8.6^{\circ} \mathrm{C}$. The accuracy of temperature measurement by this probe was checked by using a calibrated standard mercury thermometer with an absolute accuracy of $0.05^{\circ} \mathrm{C}$ (Fig. 4). As can be seen in Figure 4, it takes about 6 min to attain $95 \%$ of the temperature change of 22 degrees. It takes, however, about $20 \mathrm{~min}$ to equilibrate the probe to the water temperature within $0.05^{\circ} \mathrm{C}$ in this case. Because sudden temperature changes in actual down-hole measurements were normally less than $10^{\circ} \mathrm{C}$, a 20 -min wait would be enough to obtain a temperature within an accuracy of $0.1^{\circ} \mathrm{C}$.

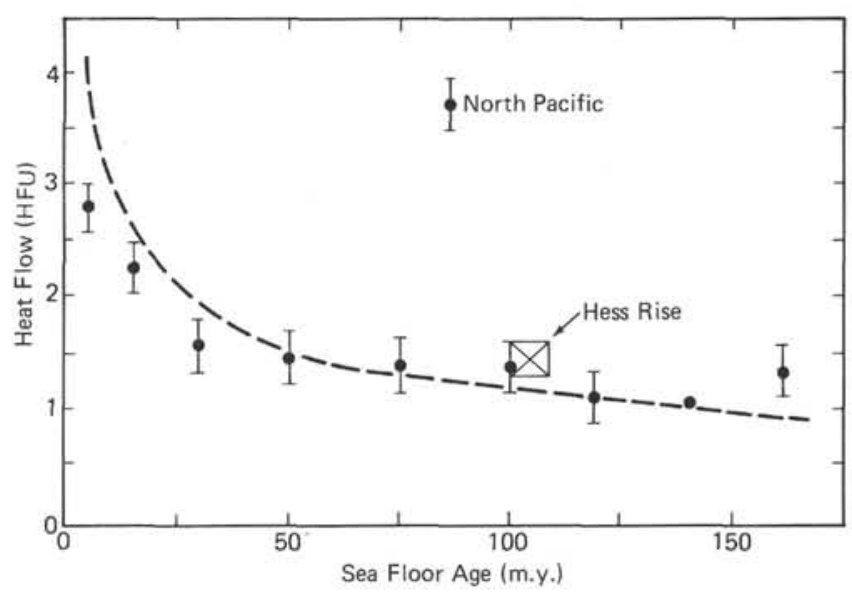

Figure 3. Estimated heat flow at Hess Rise, compared with valües for the North Pacific basin (Sclater and Francheteau, 1970) and theoretical heat flow as a function of sea-floor age. 


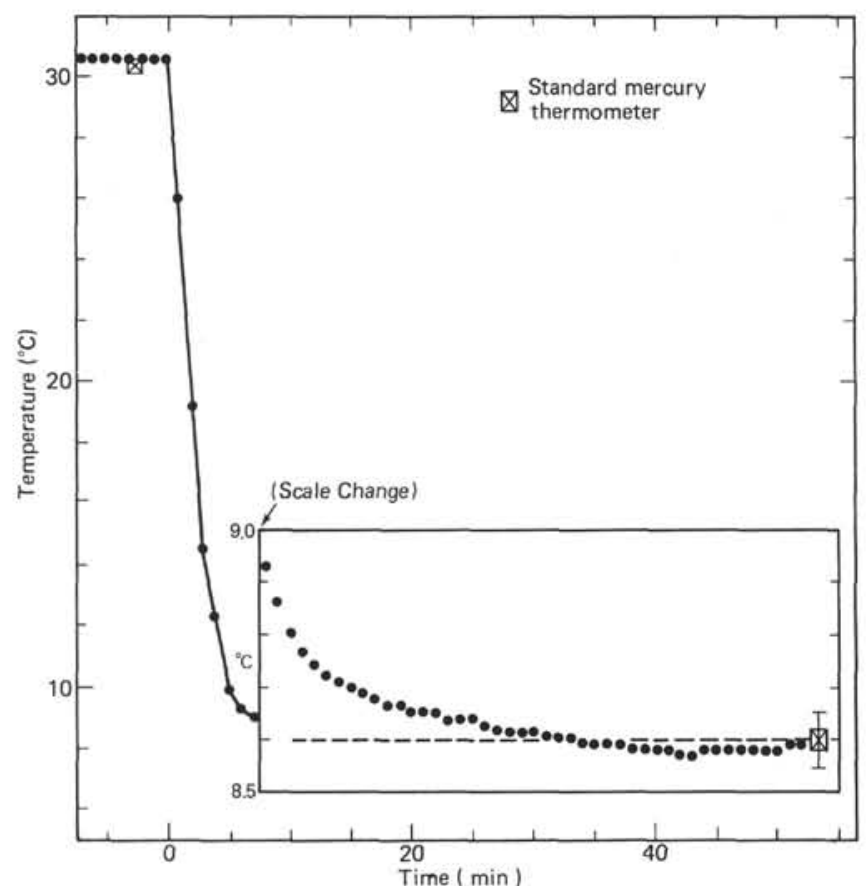

Figure 4. Variations of temperature with time for a sudden temperature change of $22^{\circ} \mathrm{C}$. The values of a calibrated standard mercury thermometer are indicated.

\section{ACKNOWLEDGMENTS}

The author would like to thank T. Vallier and J. Thiede (Co-Chief Scientists of Leg 62) for their encouragement, and R. Knapp and M. Lehman of the Glomar Challenger for their assistance. The author also thanks S. Uyeda and the late Y. Matsubara for their interest and preparation of the calibrated thermisters used in this study. S. Karato and $\mathrm{N}$. Isezaki made critical reviews and gave valuable suggestions.
Drafts and typing assistances by K. Fujimoto and J. Asakura were helpful. This work was partly supported by the Japanese IPOD Committee and a grant from the Ministry of Education.

\section{REFERENCES}

Erickson, A. J. 1974. Initial report on downhole temperature and shipboard thermal conductivity measurements, Leg 19. In Creager, J. S., Scholl, D. W., et al., Init. Repts. DSDP., 19: Washington (U. S. Govt. Printing Office), 643-656.

Horai, K., in press. Thermal conductivity of oceanic crustal samples collected during DSDP Leg 60 drilling. In Hussong, D., Uyeda, S., et al., Init. Repts. DSDP., 60: Washington (U. S. Govt. Printing Office).

Hyndman, R. D., Von Herzen, R. P., Erickson, A. J., et al., 1977. Heat-flow measurements, DSDP Leg 37. In Aumento, F., Melson, W. G., et al., Init. Repts. DSDP., 37: Washington (U. S. Govt. Printing Office), 347-362.

Moberly, R., and Larson, R. L., 1975. Mesozoic magnetic anomalies, oceanic plateaus, and sea mount chains in the northwestern Pacific ocean. In Larson, R. L., Moberly, R., et al., Init. Repts. DSDP., 32: Washington (U. S. Govt. Printing Office), 945-957.

Ratcliffe, E. H., 1960. Thermal conductivities of ocean sediments. $J$. Geophys. Res., 65:1535-1541.

Sclater, J. G., and Francheteau, J., 1970. The implications of terrestrial heat flow observations on current tectonic and geochemical models of the crust and upper mantle of the earth. Geophys. J. Royal Astron. Soc., 20:509-542.

Sumikawa, S., and Arakawa, Y., 1974. Quick thermal conductivity meter. Instrumentation Automation, 4:60.

Tokuyama, E., in press. Cretaceous volcanism in central Pacific ocean. J. Geogr. [in Japanese with English abstract]

Uyeda, S., and Horai, K., in press. Heat flow measurements, DSDP Leg 60. In Hussong, D., Uyeda, S., et al., Init. Repts. DSDP., 60: Washington (U. S. Govt. Printing Office).

Von Herzen, R. P., and Maxwell, A. E., 1959. The measurement of thermal conductivity of deep-sea sediments by a needle probe method. J. Geophys. Res., 64:1557-1563.

Yokota, T., Kinoshita, H., and Uyeda, S., in press. New DSDP (Deep Sea Drilling Project) downhole temperature probe utilizing digital self-recording system with IC RAM elements. Bull. Earthquake Res. Inst. 